\title{
Waveform characterization of the soybean stem feeder Edessa meditabunda: overcoming the challenge of wiring pentatomids for EPG
}

\author{
T. Lucini ${ }^{1}$ \& A. R. Panizzi ${ }^{2 *}$ \\ ${ }^{1}$ Departament of Zoology, Federal University of Paraná, PO Box 19020, Curitiba, PR 81531-980, Brazil, and ${ }^{2}$ Laboratory of \\ Entomology, Embrapa Wheat, PO Box 3081, Passo Fundo RS, 99001-970, Brazil
}

Accepted: 24 August 2015

Key words: true bugs, stink bug, electrical penetration graph, electropenetrograph, electronic monitoring of feeding, insect wiring methodology, behaviour, Hemiptera, Heteroptera,

Pentatomidae, Glycine max, Fabaceae

\begin{abstract}
Stink bugs (Hemiptera: Heteroptera: Pentatomidae) are in general robust and restless insects, which makes them difficult to wire for electropenetrograph (EPG) studies. In addition, cuticular lipids may reduce wire effectiveness, and their removal could improve success of wiring. We compared wiring effectiveness for three species of stink bugs, differing in walking behaviour and degree of cuticular waxiness, that is, Piezodorus guildinii (Westwood), Nezara viridula (L.), and Loxa deducta (Walker). Results indicated that removal of cuticular lipids by mechanical abrasion (via sanding) greatly improved attachment success with gold wire. Our hypothesis that heavier and bigger bugs would lose the wire attachment more quickly than lighter and smaller bugs was not confirmed, regardless of the sanding. In contrast, our hypothesis that greater movement of a bug would cause the wire to break more often was supported by extensive testing. Behaviour appears to be more relevant for successful wiring than body weight. We used the sanding and wiring technique to characterize and correlate direct current EPG waveforms for the large and restless stem-feeding stink bug Edessa meditabunda (Fabricius) on soybean plants. This marks the first published example of pentatomid EPG waveforms. Edessa meditabunda recordings on soybean stems generated eight types of waveforms in three phases and two families, named as follows: non-probing $=\mathrm{Np}$ and Z; pathway phase $=\mathrm{Em} 1$; X wave phase $=X$; ingestion phase, family $\mathrm{I}=\mathrm{Em} 2$ and $\mathrm{Em} 3$; ingestion phase, family $\mathrm{N}=\mathrm{Em} 4$ and Em5. These eight were described based on their frequencies, relative amplitudes, and level voltages. Histological studies of stylets within salivary sheaths correlated the Em1, Em2, and Em3 waveforms with specific penetration sites. The waveform with the longest duration when feeding was Em2, representing xylem sap ingestion; in addition, waveform Em3 (always preceded by an X wave) was correlated with phloem sap ingestion.
\end{abstract}

\section{Introduction}

The study of the feeding activity of plant-sucking insects was revolutionized with the introduction of the electronic monitoring system developed by McLean \& Kinsey (1964) and further improved by Tjallingii (1978). This technique, known now as electrical penetration graph (Tjallingii, 1985), or electropenetrograph (both abbreviated EPG),

*Correspondence: A. R. Panizzi, Laboratory of Entomology, Embrapa Wheat, PO Box 3081, Passo Fundo, RS 99001-970, Brazil.

E-mail: antonio.panizzi@embrapa.br allows observing and measuring of otherwise invisible stylet penetration/probing inside the opaque food. EPG has become popular among researchers studying plantfeeding hemipterans. It was first used for aphids (McLean \& Kinsey, 1964, 1965) and, later, for other sternorrhynchans, such as whiteflies (Janssen et al., 1989; Jiang et al., 2001; Yin et al., 2010), scales (Calatayud et al., 1994, 2001), and psyllids (Bonani et al., 2010; Cen et al., 2012), and for auchenorrynchans, such as leafhoppers (Almeida \& Backus, 2004; Stafford et al., 2009; Jin et al., 2012).

Regarding true bugs (Hemiptera: Heteroptera), much fewer EPG studies of feeding behaviour have been conducted. The species studied include Lygus hesperus Knight 
(Cline \& Backus, 2002; Backus et al., 2007), Trygonotylus caelestialium (Kirkaldy), and Stenotus rubrovittatus (Matsumura) (Suzuki \& Hori, 2014) (all Miridae), Anasa tristis DeGeer (Coreidae) (Bonjour et al., 1991; Cook \& Neal, 1999), and Blissus insularis Barber and Blissus occiduus Barber (Blissidae) (Backus et al., 2013). To our knowledge, no published EPG studies have been performed with stink bugs (Pentatomidae). Feeding strategies for pentatomids are highly variable, as they use both the salivary sheath and the lacerate-and-flush (renamed 'cell-rupture'; Backus et al., 2005b) strategies according to host plants and circumstances (Hori, 2000). For example, Palomena angulosa Motschulsky uses a salivary sheath when feeding on the phloem, but cell rupturing when feeding on fruit (Hori et al., 1984). It is unknown whether EPG waveforms for pentatomids are highly diverse based on strategy used.

Compared to other plant-sucking insects studied using the EPG, stink bugs are, in general, bigger, much more robust, and move around generating strong pulls that detach their wires needed to generate the voltage circuit. Therefore, a successful wiring of stink bugs should take into consideration their activity. In addition, the dense cuticular lipids present on the body surface are a potential problem that can prevent successful attachment of the gold wire to the bugs, as well as conductivity of electrical signals. For example, cuticular lipids on the body surface of the pentatomid Nezara viridula (L.) are hydrophobic (SosaGomez et al., 1997). Because the silver glue used to attach the gold wire to the insect body is water-based, these lipids may reduce the effectiveness of the attachment. Therefore, the removal of cuticular lipids could improve wiring success and conductivity.

In this paper, we report the results of studies with four species of pentatomids. To test the effectiveness of wiring, we compared adult females with different body sizes, and different behaviours, that is, Piezodorus guildinii (Westwood), N. viridula, and Loxa deducta (Walker). We also compared the wiring attachment effectiveness between bugs that had their cuticular lipids mechanically removed (by sanding) with those that were unsanded; sanding proved a highly effective technique. Finally, we used the sanding-before-wiring method to characterize and correlate the direct current (DC) EPG waveforms of the stemfeeding stink bug, Edessa meditabunda (Fabricius) on Soybean plants.

\section{Material and methods}

\section{Stink bug rearing and Soybean plants}

Colonies of the stink bugs P. guildinii, N. viridula, $L$. deducta, and E. meditabunda were established in the laboratory. Adults were field-collected at the Embrapa Wheat experiment station at Passo Fundo, RS, Brazil $\left(28^{\circ} 15^{\prime} \mathrm{S}\right.$, $\left.52^{\circ} 24^{\prime} \mathrm{W}\right)$. Insects were transported to the laboratory and placed in clear plastic rearing boxes $(25 \times 20 \times 20 \mathrm{~cm})$ (Plasvale, Gaspar, SC, Brazil), lined with filter paper and provided with fresh pods of green bean, Phaseolus vulgaris L., raw shelled peanuts, Arachis hypogaea L., mature seeds of soybean, Glycine max (L.), and fruits (berries) of privet, Ligustrum lucidum Ait. Despite preferring to feed on soybean stems, E. meditabunda successfully developed and reproduced using the mixtures of foods provided.

From October 2013 to July 2014, rearing boxes were kept in a walk-in chamber at $25 \pm 1{ }^{\circ} \mathrm{C}, 65 \pm 5 \%$ r.h., and L14:D10 photoperiod. Food was checked daily and replaced when necessary. The colony was genetically invigorated every month with the addition of more field-collected adults, and nymphs obtained were raised to the adult stage. Soybean seeds cv. Tordilha were sown in small pots $(100 \mathrm{ml})$ in a greenhouse, and plants of ca. $15 \mathrm{~cm}$ high (stage V1) were used for the EPG studies.

\section{Wiring the adult stink bugs}

To attach the gold wire onto the pronota of the stink bugs, adult females were immobilized using an adhesive tape (PL Mitchell, pers. comm.) on the top of a Petri dish lid, then attached to the posterior part of the abdomen. The gold wire ( $3 \mathrm{~cm}$ long, and $0.1 \mathrm{~mm}$ in diameter) (Sigmund Cohn, Mount Vernon, NY, USA) was glued to a copper electrode ( $3 \mathrm{~cm}$ long) that had previously been soldered to a brass nail; together, the reusable copper wire plus brass nail are termed a 'wiring stub'. At the tip of the gold wire, a small loop $(0.5 \mathrm{~mm})$ was made to expand the surface of gold area in contact with the stink bug pronotum using conductive silver glue. This glue was made by mixing water, silver flakes (Sigma-Aldrich, Saint Louis, MO, USA), and white glue (Elmer's Glue-All, Westerville, $\mathrm{OH}$, USA) (1:1:1 vol/wt/vol). A drop of the silver glue was placed on the centre of the pronotum, and the loop of the gold wire was sunk into the glue, where it was allowed to dry for $40 \mathrm{~min}$. After that, the bugs were released (the adhesive tape was carefully removed to avoid damaging the bug) and were allowed to dangle from the wiring stub for $10 \mathrm{~min}$ before they were used with the EPG monitor.

\section{Cuticular lipid removal, body weight and size, and silver glue drop size affecting wiring}

To study the effect of removing cuticular lipids on the effectiveness of the gold wire attachment to the stink bug's pronotum, two groups of bugs of each species were wired ( $n=15$ per species, all females). In group one, bugs were immobilized using adhesive tape on a plastic surface (as described above) and had their pronota sanded using a piece of human dental sandpaper, model MF 435L 
$(2.0 \times 0.4 \mathrm{~cm})$ (Metalúrgica FAVA, São Paulo, SP, Brazil) which was passed over the insect $10 \times$ (ca. $10 \mathrm{~s}$ ); the areas scraped received the drop of the silver glue for wiring. In group two, the bugs were immobilized and wired in similar fashion, but their pronota were not sanded.

Each of the two groups of bugs was tested in two situations. In the first case, wired bugs were clamped on a ring stand free in the air (dangling); in the second case, immediately after the glue's drying time was finished, they were clamped and then placed on the food (a pod of green bean). The number of bugs that had become detached from the gold wire was recorded at 5, 10, 20, 40, 80, and $960 \mathrm{~min}$ (16 h; this last time interval was selected because in many studies with EPG this time frame is used for recording waveforms) after they were clamped either in the air or on the top of the food (green bean pod).

We hypothesized that the size of the silver glue drop laid on the pronotum of adult female $N$. viridula might affect bug attachment to the gold wire over time. Therefore, the size (diameter, $\mathrm{mm}$ ) of the silver glue drop was evaluated at $0,20,40$, and $60 \mathrm{~min}(\mathrm{n}=10)$ after the drop was laid. We also compared the weight $(\mathrm{mg})$ of the glue drop $(n=60)$ after the experiment to certify that the different drops laid on the two groups of bugs - sanded and unsanded - were equivalent.

Fresh body weight (mg), body length ( $\mathrm{mm})$, and body width (mm) of P. guildinii, N. viridula, and L. deducta were recorded. These species were selected because they show differences in those traits, which could affect the effectiveness of wiring. Females of each species $(n=20)$ were used. Body weight was measured using an electronic balance (Sartorius model BP210S), and body measurements (body length $=$ from jugal point to the tip of the hemelytra; body width = greater width of the pronotum) were taken using a digital camera (Sony model DSCW215) and analysed using the software ImageJ, v.1.47.

\section{Stink bug movement affecting wiring}

We also hypothesized that the movement of the different species of stink bugs might affect wire success. Therefore, unwired female bugs ( $n=15$ of each species at the same age, ca. 10 days old) were released individually into an arena (glass Petri dish, $9 \times 15 \mathrm{~cm}$ ) lined with filter paper. The following behaviours were recorded: number of times the bugs moved, number of turns back $\left(360^{\circ}\right.$ turn), and total distance $(\mathrm{cm})$ travelled at 15, 30, 45, and $60 \mathrm{~min}$ after release of the bugs in the centre of the arena. The total distance travelled was marked with a pen on the top of the arena, and at the end of each observation period it was photographed using a digital camera (Sony model DSCW215). The distance travelled was then calculated analysing the photographs using the software ImageJ, v.1.47.
In a second test, females were wired, and the gold wire plus the wiring stub were punched into a small Styrofoam block; the insects were allowed to stand or move on a surface and drag the small block behind them. The following behaviours were recorded: number of times the bugs moved, number of turns back $\left(360^{\circ}\right.$ turn), and number of pulls, that is, number of times the bugs pull the gold wire at its maximum distance. The observation time was similar to the previous test.

\section{Electropenetrograph (EPG) recordings}

To analyse stink bug probing behaviour, we chose E. meditabunda, which feeds on stems of soybean plants. Soybeans were cultivated in small pots $(100 \mathrm{ml})$ that received the EPG plant electrode. Females of the same age (ca. 10 days) were separated from the laboratory colony and were starved for $18 \mathrm{~h}$. After this period, they were wired following the procedures previously described. After dangling for $10 \mathrm{~min}$, to make sure the gold wire was firmly attached to the bug's pronotum, the electrode was connected to the EPG probe (head-stage amplifier). The copper electrode (3 $\mathrm{cm}$ long) was inserted in the soil containing the plants, closing the circuit, to allow the recordings.

Twenty-five females were recorded, each during a continuous total period of $8 \mathrm{~h}$ (09:00-17:00 hours). The EPG recordings were obtained using a DC-monitor, Giga-8 model (EPG Systems, Wageningen, The Netherlands) (Tjallingii, 1988), with a fixed input resistance of $10^{9} \Omega$ and adjusted to $50 \times$ gain. The changes in mostly biopotentials during stylet probing were amplified and digitized at a rate of 100 samples per channel using a DI-710 (Dataq Instruments, Akron, OH, USA) and recorded by using a HP Pentium notebook with WinDaq Lite software (Dataq). Recordings were made in a closed room kept at $25 \pm 2{ }^{\circ} \mathrm{C}$ with artificial light, and with the control box placed inside a Faraday cage to reduce noise.

The waveforms were characterized taking into consideration previous waveforms obtained for other species of sucking insects, considering shape, amplitude, frequency, and voltage level. The relative minimum and maximum amplitudes of each waveform were determined in comparison with the waveform with greatest amplitude during each event, considering the lowest valley to the highest peak, according to Backus et al. (2013). Waveform amplitude and frequency were estimated based on the average of six observations for each insect, totalling ca. 150 observations for each waveform.

\section{Plant tissue histology}

Correlations between the stylet position in soybean stem tissue and different waveforms observed during EPG 
recordings were performed via histology. For this study, a second set of E. meditabunda adult females was recorded using the same conditions as the previous EPG recordings. When the respective waveform of interest was observed, the EPG monitor was turned off and the stylets were carefully cut using a pair of entomological microscissors. Cutting was very gentle and did not disturb the stylet's position in the plant. In addition, the processing steps were minimal and gentle, and did not dislodge the stylets. Next, a piece of soybean stem (ca. $2 \mathrm{~cm}$ long) around the styletinsertion site was excised. Then, this piece of tissue containing the severed stylets was carefully hand-cut into thin sections using a sharp razor blade (Wilkinson Sword, High Wycombe, UK) under an M5A stereomicroscope (Wild, Heerbrugg, Switzerland).

The stem sections were placed separately in Petri dishes containing 1:1 vol:vol water:commercial sodium hypochlorite (10\%) solution (bleach) to clear the tissues. After a few minutes, the sections were rinsed in distilled water and subsequently stained in 1\% toluidine blue solution for $5 \mathrm{~min}$ (Sigma-Aldrich, St. Louis, MO, USA). Next, semi-permanent slides were prepared in glycerinated gelatin and examined using an Olympus BX50 microscope (Shinjuku, Tokyo, Japan). The position of the stylet tips in the soybean stem was determined based on three specimens for waveform Em1, eight specimens for Em2, and six specimens for Em3. Digital images were captured, using the same microscope coupled with a Sony DXC 107A video camera (Minato, Tokyo, Japan) linked to a computer.

\section{Statistical analysis}

Data on female traits (fresh body weight, body length, and body width) were compared via analysis of variance (ANOVA), and means were separated using the Tukey test $(\alpha=0.05)$. Data on silver glue drop size and weight were analysed in a similar way, except that for the comparison of the contrasts (two means) of sanded vs. unsanded bugs, the Student's t-test was used. The percentage of gold wire retention over time on a green bean pod, comparing sanded vs. unsanded bugs within each bug species and among them, were analysed using the $\chi^{2}$ test. Data on the effect of movement of the various species of stink bugs on gold wire attachment times were analysed via ANOVA and the Tukey test $(\alpha=0.05)$. EPG waveform events were measured sequentially using WinDaq Waveform Browser (Dataq), then five non-sequential response variables from Backus et al. (2007) were calculated. These variables were as follows: NPW, number of individuals that produced the specific waveform; NWEI, number of waveform events per insect; WDI, waveform duration per insect (min);
WDEI, waveform duration per event per insect (min); and PRT, percentage of recording time for each waveform. All statistics were performed using R, v.3.0.3 ( $\mathrm{R}$ Development Core Team, 2014).

\section{Results}

Cuticular lipid removal, body weight and size, and silver glue drop size affecting wiring

The effect of removing cuticular lipids (i.e., bugs sanded at the site the silver glue was dropped onto the pronotum vs. unsanded bugs) on the percentage of adult females on the green bean pod that remained attached to the gold wire over time differed among the species of stink bugs tested (Figure 1). Data obtained for bugs that were left dangling did not show any significant differences, and therefore are not shown.
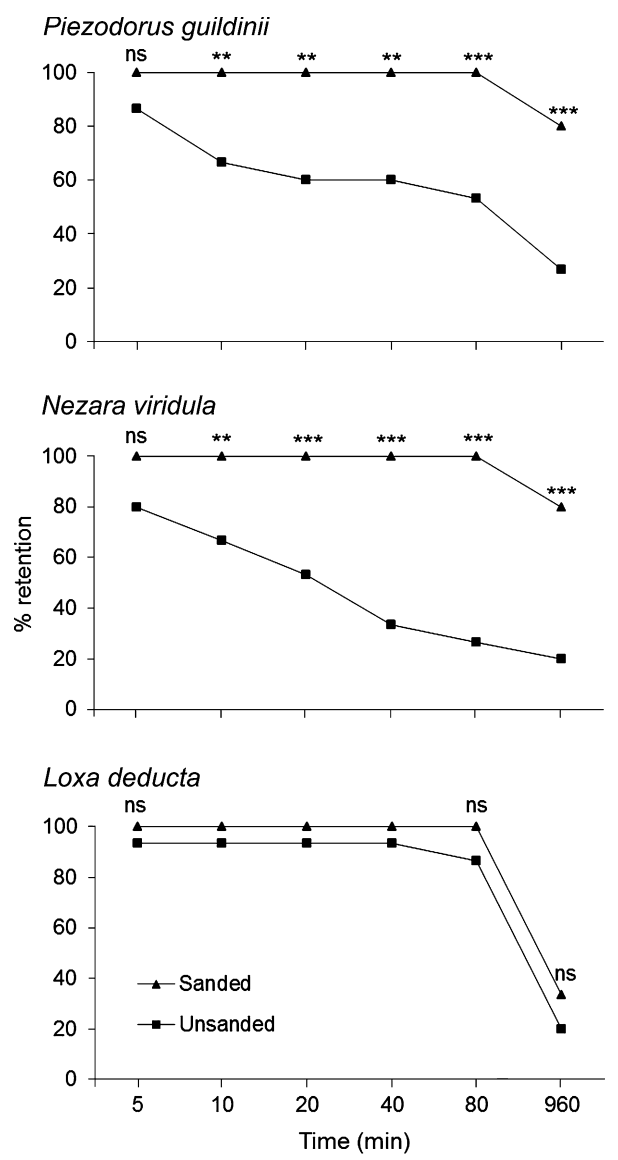

Figure 1 Effect of sanded vs. unsanded pronotum of Piezodorus guildinii, Nezara viridula, and Loxa deducta on the percentage of adult females attached to the gold wire over time, on a green bean pod. Asterisks indicate significant differences between treatments within a time period $\left(\chi^{2}\right.$ tests: $* * 0.001<\mathrm{P}<0.01$, $* * * \mathrm{P}<0.001$; ns, non-significant; $\mathrm{n}=15$ ). 
For P. guildinii and N. viridula, during all time intervals except for the first $5 \mathrm{~min}$, the percentage of bugs that remained attached to the wire was significantly greater than that observed for the unsanded bugs; only after $960 \mathrm{~min}, 20 \%$ of the sanded bugs lost the attachment. On the other hand, for the unsanded bugs, the percentage of retention gradually decreased with time, going down to 20-25\% after 960 min (Figure 1). With L. deducta, a different result was obtained: no significant differences were observed over time, the attachment remained high $(\geq 90 \%$ ), except after $960 \mathrm{~min}$, when it dropped to $20-30 \%$ for both sanded and unsanded bugs (Figure 1). The weight and morphological traits of the three species differed significantly; P. guildinii were the smallest, whereas $L$. deducta were the biggest (Table 1 ). The diameter of the silver glue drop laid on the pronotum of sanded adult female $N$. viridula was significantly greater at 0 $60 \mathrm{~min}$ than the diameter of drops on unsanded bugs. However, the weight of the silver glue drops laid on sanded and unsanded bugs was the same (Table 2).

\section{Stink bug movement affecting wiring}

Stink bug movement appeared to differ greatly among the species examined. When unwired bugs were released in the arenas, $P$. guildinii displayed a significantly greater total number of movements at 15, 30, 45, and 60 min after release in the arena, compared to L. deducta; P. guildinii was also more restless than $N$. viridula at the 15 -min

Table 1 Mean $( \pm$ SEM) weight and phenological traits of three species of pentatomids tested in wiring for EPG studies

\begin{tabular}{lccr}
\hline & $\begin{array}{l}\text { Body weight } \\
(\mathrm{mg})\end{array}$ & $\begin{array}{l}\text { Body length } \\
(\mathrm{mm})\end{array}$ & \multicolumn{1}{l}{$\begin{array}{l}\text { Body width } \\
(\mathrm{mm})\end{array}$} \\
\hline $\begin{array}{l}\text { Piezodorus } \\
\text { guildinii }\end{array}$ & $53.1 \pm 0.35 \mathrm{c}$ & $9.4 \pm 0.07 \mathrm{c}$ & $5.1 \pm 0.04 \mathrm{c}$ \\
$\begin{array}{l}\text { Nezara viridula } \\
\text { Loxa deducta }\end{array}$ & $142.7 \pm 0.55 \mathrm{~b}$ & $14.8 \pm 0.14 \mathrm{~b}$ & $8.4 \pm 0.10 \mathrm{~b}$ \\
\hline
\end{tabular}

Means within a column followed by different letters are significantly different (Tukey test: $\mathrm{P}<0.05 ; \mathrm{n}=20$ ). recording time, but not later on (Figure $2 \mathrm{~A})$. The number of $360^{\circ}$ turns was $3 \times$ higher for P. guildinii compared to N. viridula and L. deducta at each time interval; the latter two species did a similar number of turns (Figure 2B). The total distance travelled at the four time intervals was similar for $N$. viridula and P. guildinii, and it was longer than for $L$. deducta (Figure 2C).

Wired bugs yielded (in general) similar results. For instance, adults of P. guildinii moved more often than L. deducta and N. viridula adults (Figure 3A). Adult $P$. guildinii made more $360^{\circ}$ turns than both other species, although the difference was not significant at every recording interval (Figure 3B). Overall, N. viridula bugs pulled the gold wire to its maximum distance more often than P. guildinii or L. deducta, a difference that was significant at some, but not at other time intervals (Figure 3C).

\section{Characterization of waveforms from EPG recordings}

General overview of EPG waveforms. On soybean plants, eight waveform types were recorded from adults of E. meditabunda, based on their frequency, relative amplitude, and level voltage (Table 3, Figures 4-6). As with other EPG studies, their coarse structure divided them into non-probing (NP and $\mathrm{Z}$ ) and probing waveforms. The latter were composed of three main phases: (1) pathway phase, (2) ingestion phase, and (3) a transitional phase between pathway and ingestion, called the $\mathrm{X}$ wave. The pathway phase comprised one waveform type (Em1). The ingestion phase consisted of two families of waveforms: I (ingestion) and N (interruption). Family I included waveform types Em2 and Em3; family $\mathrm{N}$ included Em4 and Em5.

Non-probing waveforms ( $N p$ and $Z$ ). These waveforms occurred when the insect was not stylet probing. Np was the most frequently repeated waveform for each insect $(61.4 \times)$ with average duration of $0.6 \mathrm{~min}$ per event (representing $7.5 \%$ of the time spent by an average insect during the $8 \mathrm{~h}$ of recording). This waveform exhibited

Table 2 Mean ( \pm SEM) diameter $(\mathrm{mm})$ of the silver glue drop on the sanded or unsanded pronotum of Nezara viridula adult females over time and drop weight $(\mathrm{mg})$ after $60 \mathrm{~min}$

\begin{tabular}{|c|c|c|c|c|c|}
\hline \multirow[b]{2}{*}{ Pronotum } & \multicolumn{4}{|c|}{ Time $(\min )(\mathrm{n}=10)$} & \multirow[b]{2}{*}{ Weight $(\mathrm{n}=60$} \\
\hline & 0 & 20 & 40 & 60 & \\
\hline Sanded & $2.77 \pm 0.05 \mathrm{aA}$ & $2.85 \pm 0.05 \mathrm{aA}$ & $2.82 \pm 0.05 \mathrm{aA}$ & $2.83 \pm 0.04 \mathrm{aA}$ & $1.14 \pm 0.03 \mathrm{~A}$ \\
\hline Unsanded & $2.60 \pm 0.05 \mathrm{aB}$ & $2.62 \pm 0.06 \mathrm{aB}$ & $2.66 \pm 0.05 \mathrm{aB}$ & $2.66 \pm 0.06 \mathrm{aB}$ & $1.15 \pm 0.04 \mathrm{~A}$ \\
\hline
\end{tabular}

Means within a row followed by the same lower case letter do not differ significantly (Tukey test: $\mathrm{P}>0.05$ ), and means within a column followed by different upper case letters differ significantly (Student's t-test: $\mathrm{P}<0.05$ ). 

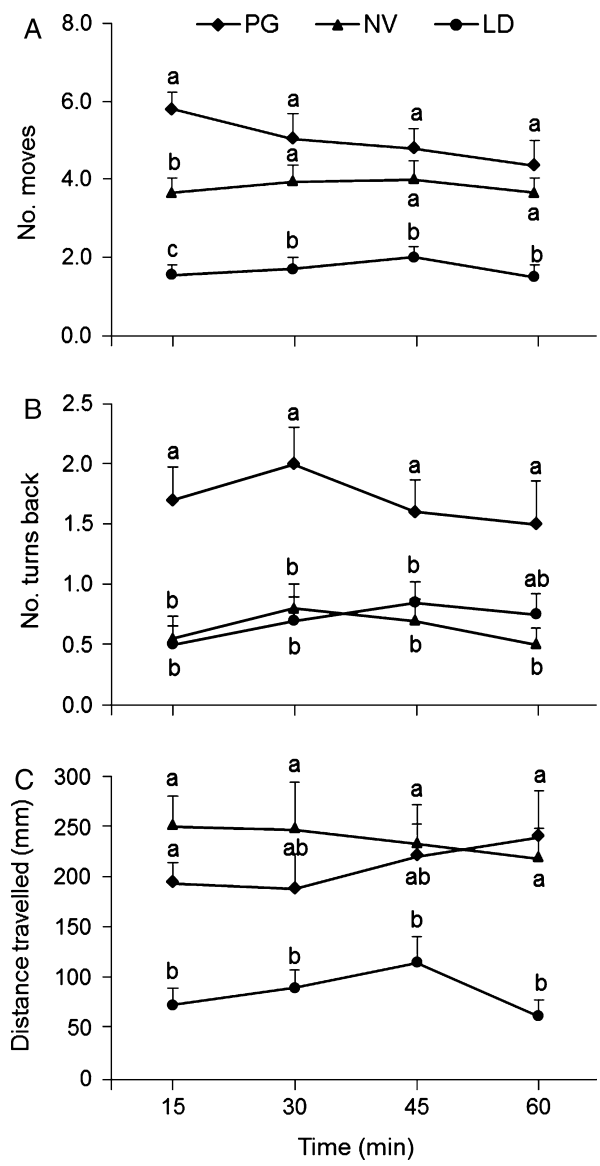

Figure 2 Movement activities over time (mean + SE) of unwired adult females of Piezodorus guildinii (PG), Nezara viridula (NV), or Loxa deducta (LD), in an arena (15 cm diameter) lined with filter paper. (A) Number of movements from one point to another, (B) number of turns back $\left(360^{\circ}\right)$, and (C) total distance travelled. Means within a time interval marked with the same letter do not differ significantly (Tukey test: $\mathrm{P}>0.05 ; \mathrm{n}=15$ ).

high amplitude and irregular frequency with several peaks; it occurred either when the insect was walking on the stem or when it touched the plant surface with its rostrum (labium). Waveform $\mathrm{Z}$ was low amplitude with very little variation in voltage, and it represented the baseline, with the insect static on the stem surface. $\mathrm{Z}$ occupied most of the recorded time, ca. $43 \%$ (Tables 3 and 4, Figure 4).

Pathway phase (Em1). Waveform Em1 represents the first electrical contact between the stink bug mouthparts (stylets) and the plant tissue, because it was the first waveform associated with probing. In addition, labial bending combined with stylet movements was often observed at the end of each probe, when the waveform returned to Em1 and the stink bug withdrew its stylets from the plant tissue; this was frequently followed by a
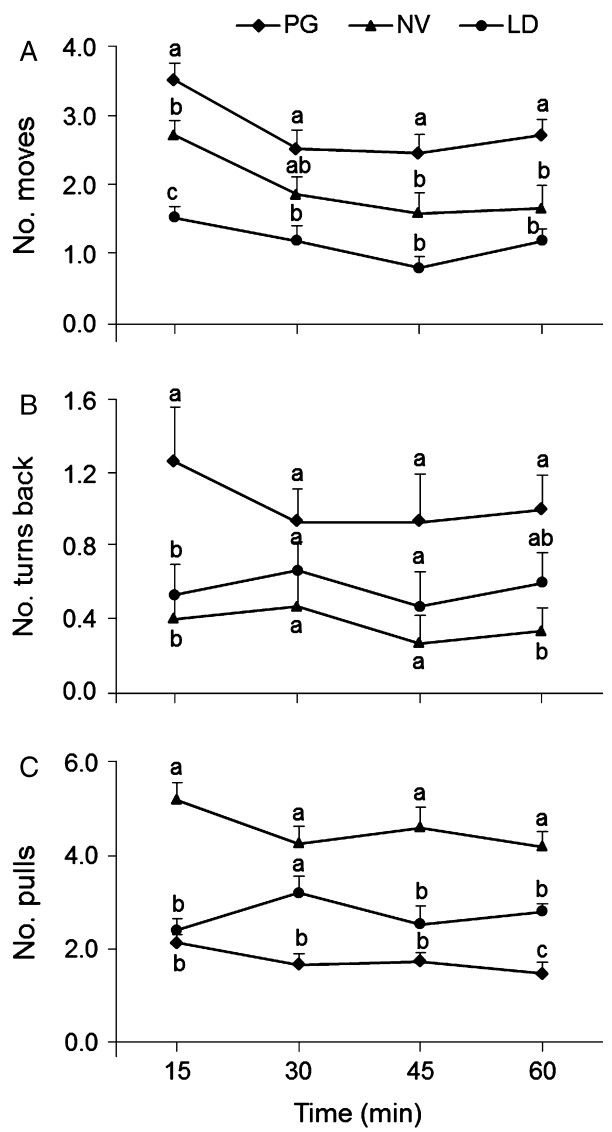

Figure 3 Behavioural traits over time (mean + SE) of wired adult females of Piezodorus guildinii (PG), Nezara viridula (NV), or Loxa deducta (LD), in an arena (15 cm diameter) lined with filter paper. (A) Number of movements from one point to another, (B) number of turns back $\left(360^{\circ}\right)$, and (C) number of gold wire pulls. Means within a time interval marked with the same letter do not differ significantly (Tukey test: $\mathrm{P}>0.05$; $\mathrm{n}=15)$.

non-probing phase, with $\mathrm{Z}$ and $\mathrm{Np}$ waveforms (Figure 5D).

Em1 was recorded for all insects with an average frequency of 15.1 events per individual and with an average duration of 1.6 min per event. Em1 was irregular in frequency and had the largest relative amplitude among all the waveforms registered. Em1 presented a high voltage level at the beginning of a probe that gradually decreased as the stylets penetrated deeper into plant tissues (Tables 3 and 4 , Figure 5B-E).

$X$ wave phase. When present, the $\mathrm{X}$ wave always occurred after waveform Em1 and always was followed by waveform Em3 (Figure 6). It was a short transition wave (ca. $2.0 \mathrm{~min}$ ), and often there was a gradual increase in voltage level towards the end of waveform X (Figure 6A). 
Table 3 Main characteristics of EPG-DC waveforms and proposed stylet activities of Edessa meditabunda on stems of soybean seedlings

\begin{tabular}{|c|c|c|c|c|c|c|}
\hline Phase & Family & Type & $\begin{array}{l}\text { Relative } \\
\text { amplitude } \\
(\%)\end{array}$ & $\begin{array}{l}\text { Frequency } \\
(\mathrm{Hz})\end{array}$ & Voltage level & Proposed activities $^{1}$ \\
\hline \multirow[t]{2}{*}{ Non-probing } & \multirow[t]{4}{*}{-} & $\mathrm{Np}$ & High & Irregular & - & Walking on the plant surface and labial tapping \\
\hline & & $\mathrm{Z}$ & Low & - & - & Standing still \\
\hline Pathway & & Em1 & 100 & Irregular & $\begin{array}{l}\text { Intracellular/ } \\
\text { extracellular }\end{array}$ & Stylet pathway/salivary sheath secretion \\
\hline $\mathrm{X}$ wave & & $\mathrm{X}$ & $25-45$ & $4.5-7.5$ & Intracellular & $\begin{array}{l}\text { Penetration of phloem cell; salivation, } \\
\text { egestion, tasting of the cell }\end{array}$ \\
\hline \multirow[t]{2}{*}{ Ingestion } & \multirow[t]{2}{*}{ I } & Em2 & $40-85$ & $3.5-5.0$ & Extracellular & Xylem sap ingestion \\
\hline & & Em3 & $5-12$ & $5.5-8.5$ & Intracellular & Phloem sap ingestion \\
\hline \multirow[t]{2}{*}{ Interruption } & \multirow[t]{2}{*}{$\mathrm{N}$} & Em4 & $40-55$ & Irregular & Extracellular & Salivary interruptions during xylem ingestion \\
\hline & & Em5 & $15-35$ & Irregular & Intracellular & Salivary interruptions during phloem ingestion \\
\hline
\end{tabular}

${ }^{1}$ Based on previous studies performed with piercing-sucking insects (see references in text).

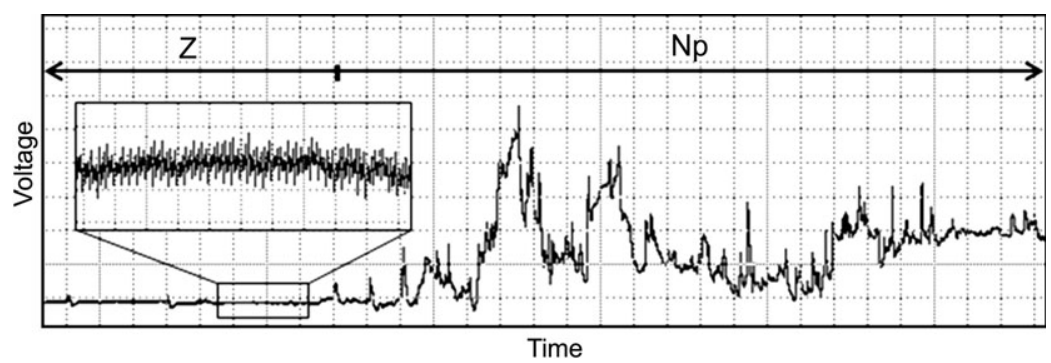

Figure 4 Electrical penetration graph (EPG-DC) waveforms Z (standing still) and Np (walking or tapping with rostrum on plant surface) recorded from Edessa meditabunda adult on stem of soybean seedling (Windaq compression 5, 1 s per vertical division, gain $4 \times, 30 \mathrm{~s}$ ). Expanded box showing waveform Z (Windaq compression 1, $0.2 \mathrm{~s}$ per vertical division, gain $128 \times, 2 \mathrm{~s}$ ).

Furthermore, a brief but abrupt voltage drop at the end of $\mathrm{X}$ was observed (Figure $6 \mathrm{~B}$ ), which marks the beginning of waveform Em3 (Figure 6C-E). The X wave had a small underlying waveform with medium amplitude and high frequency (4.5-7.5 Hz; Table 3). Usually there was only one $\mathrm{X}$ wave (episode) before the bug starting a sustained waveform Em3.

Ingestion phase. Family I (Em2 and Em3)-Family I was composed of two waveform types, Em2 and Em3. Waveform Em2 always occurred immediately after waveform Em1 without an intervening X wave. Em2 was composed of repetitive waves interspersed with upward peaks (defined in Figure 5G), which occurred at regular intervals (Figure 5G-H). Sometimes, larger peaks were observed on top of a higher-amplitude plateau (Figure $5 \mathrm{H}$ ). The waveform Em2 was high in relative amplitude (ranging from 40 to $85 \%$ ), had a voltage level mostly extracellular (positive), and consisted of medium frequency, ranging from 3.5 to $5.0 \mathrm{~Hz}$. All insects performed this waveform, representing most of the recorded probing time (30.6\%). Em2 occurred for (on average) 3.4 events per insect, and it typically had a long duration, averaging $61.6 \mathrm{~min}$ per event (9.3-172.4 min) (Tables 3 and 4).

Waveform Em3 was always preceded by an X wave. It had an overlying, large-scale, and irregular, sinuous form, that is, alternating up and down at a frequency of about $0.1 \mathrm{~Hz}$, but always with upward large-scale peaks (Figures $5 \mathrm{I}-\mathrm{K}$ and $6 \mathrm{C}-\mathrm{E})$. Superimposed on this sinuous wave was an underlying, much smaller waveform, highly regular with a frequency of 5.5-8.5 Hz. Usually, waveform Em3 showed a low-amplitude (5-12\%) intracellular voltage level (negative). It was observed in $44 \%$ of the insects recorded and repeated less than once for each average insect; nevertheless, Em3 showed long duration per insect, ca. $100 \mathrm{~min}$ per event $(8.2-310.7 \mathrm{~min})$, thus representing $12.9 \%$ of the recorded time (Tables 3 and 4, Figure 5I).

Interruption phase. Family $N$ (Em4 and Em5)-This family comprised short interruptions $(<5 s)$ that occurred within waveforms Em2 and Em3, but more frequently in 


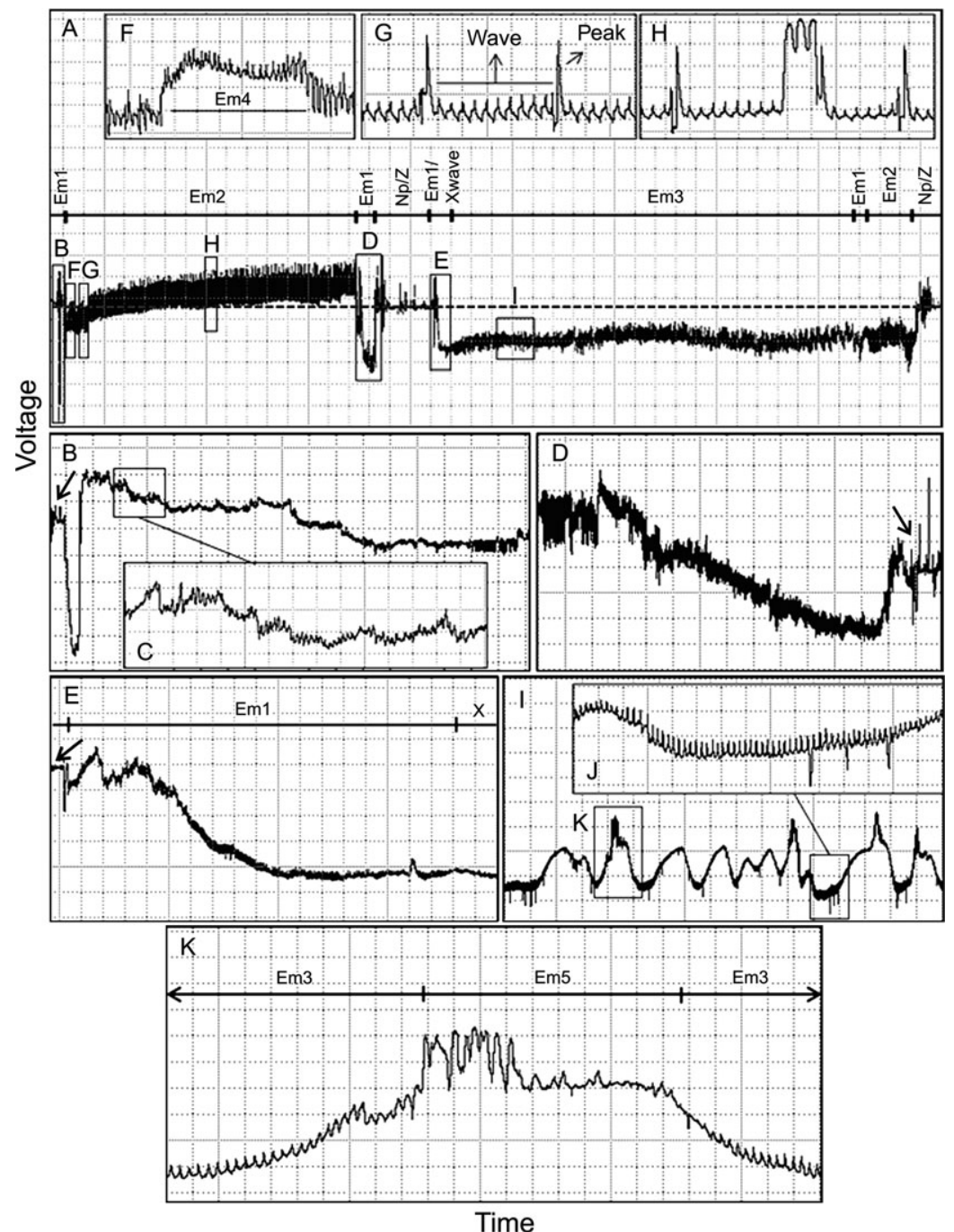

Figure 5 Waveforms generated using EPG-DC recorded from Edessa meditabunda adult on stem of soybean seedling. (A) Compressed overview of feeding from two probes (290 min, Windaq compression 2000, $400 \mathrm{~s}$ per vertical division). This first box shows non-probing ( $\mathrm{N}$ and $\mathrm{Z}$ ), pathway (Em1), xylem sap ingestion (Em2), the $\mathrm{X}$ wave, and phloem sap ingestion (Em3). (B, C) Expanded views of waveform $\mathrm{Em} 1$ and the $\mathrm{X}$ wave from small boxes with corresponding letters, in part $\mathrm{A}$ ( $\mathrm{B}$ has Windaq compression 40, 8 s per vertical division, gain $2 \times$; C has compression 5, 1 s per vertical division, gain $8 \times$ ). (D) Expanded view of partial stylet withdrawal at the end of waveform Em1 (compression 30, 6 s per vertical division, gain 4X). (E) Waveform Em1 and beginning of the $\mathrm{X}$ wave (compression 30, 6 s per vertical division, gain $4 \times$ ). (F-H) Expanded views of waveform Em2. (F) The interruption (wave Em4) during waveform Em2 (compression 4, 0.8 s per vertical division, gain $8 \times$, ca. 9 s). (G) Definition of wave vs. peak (compression 3, 0.6 s per vertical division, gain $8 \times, 6.6 \mathrm{~s}$ ). (H) Detail of the larger peak during waveform Em2 (compression 3, 0.6 s per vertical division, gain $8 \times, 7.2 \mathrm{~s}$ ). (I-K) Expanded views of waveform Em3 (I has compression 30, 6 s per vertical division, gain $8 \times, 102 \mathrm{~s}$; J has compression 3, 0.6 s per vertical division, gain $16 \times$, $9 \mathrm{~s}$ ). (K) Expanded view of waveform Em3 interspersed with interruptions (wave Em5) (compression 2, 0.4 s per vertical division, gain $16 \times, 10 \mathrm{~s})$. Arrows and dashed line indicate baseline.

Em3. It was divided into two waveform types, Em4 and Em5. Waveform Em4 showed irregular form, high amplitude (40-55\%), and a flat-spike plateau (Figure 5F). It was only observed in $32 \%$ of the insects and occurred intermittently during waveform Em2. Em4 was repeated, on average, 1.4 events per insect with relatively short durations (ca. 5 s) and, if observed, it was mainly recorded at the beginning of Em2 (Tables 3 and 4, Figure 5F). Waveform Em5 is similar to waveform Em4, that is, short duration (ca. $4 \mathrm{~s}$ ), amplitude 15-35\%, and irregular frequency; however, Em5 often showed peaks with higher amplitude than waveform Em3 (Figure 5K). Unlike Em4, 


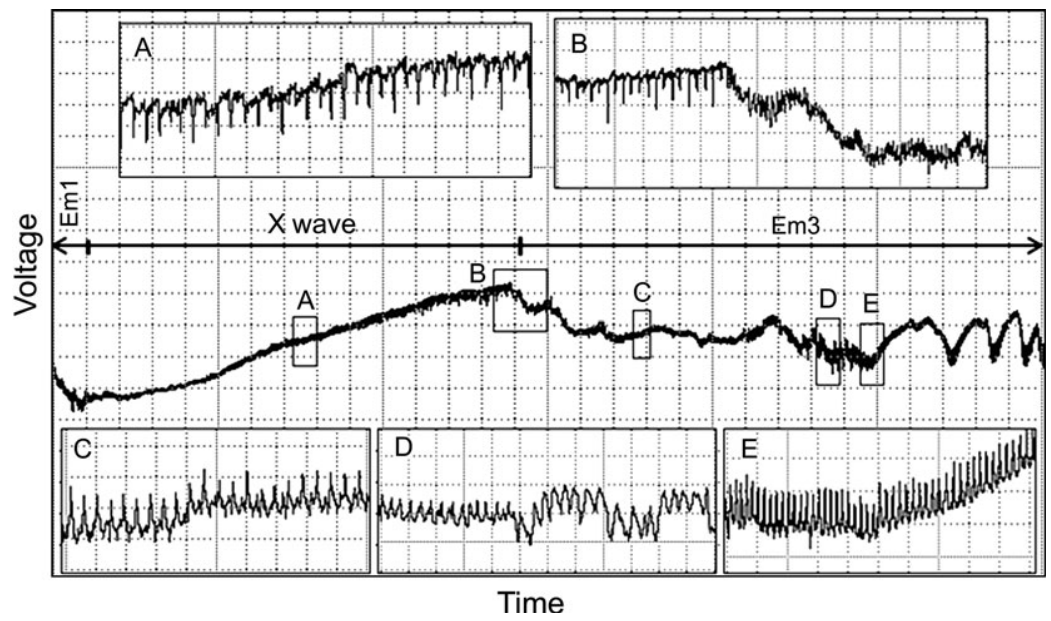

Figure 6 Waveforms $\mathrm{X}$ and $\mathrm{Em} 3$ recorded from Edessa meditabunda adult in phloem tissue from stem of soybean seedling (Windaq compression 50, 10 s per vertical division, gain 16×, 300 s). (A) Expansion of waveform $X$ for corresponding box, showing a gradual voltage rise (compression 3, 0.6 s per vertical division, gain $64 \times, 7.8$ s). (B) Transition from waveform X to Em3 (phloem sap ingestion) showing short, abrupt voltage drop (compression 5, 1 s per vertical division, gain 32×, $15 \mathrm{~s}$ ). (C-E) Expansions of waveform Em3, showing evolution in appearance over time (C has Windaq compression 2, $0.4 \mathrm{~s}$ per vertical division, gain $64 \times, 4 \mathrm{~s}$; D has compression 2, 0.4 s per vertical division, gain $16 \times, 4.8 \mathrm{~s}$; E has compression 3, $0.6 \mathrm{~s}$ per vertical division, gain $32 \times, 6 \mathrm{~s}$ ).

Table 4 Mean ( \pm SE; ranges in parentheses) EPG-DC variables used to study probing behaviour of Edessa meditabunda on stems of soybean seedlings $(\mathrm{n}=25)$

\begin{tabular}{lllllcrr}
\hline Phase & Family & Type & NPW & NWEI & WDI $(\min )$ & WDEI $(\mathrm{min})$ & PRT $(\%)$ \\
\hline Non-probing & - & $\mathrm{Np}$ & 25 & $61.4 \pm 5.7(14-140)$ & $35.9 \pm 3.9(6.9-71.7)$ & $0.6 \pm 0.1(0.3-1.3)$ & 7.5 \\
& & $\mathrm{Z}$ & 25 & - & $206.4 \pm 20.8(37.4-417.6)$ & - & 42.8 \\
Pathway & - & Em1 & 25 & $15.1 \pm 3.4(2-71)$ & $27.2 \pm 9.0(0.8-201.9)$ & $1.6 \pm 0.2(0.2-5.3)$ & 5.7 \\
X wave & - & $\mathrm{X}$ & 11 & $0.7 \pm 0.2(0-3)$ & $2.9 \pm 0.4(1.1-5.5)$ & $1.9 \pm 0.2(1.1-3.6)$ & 0.6 \\
Ingestion & $\mathrm{I}$ & Em2 & 25 & $3.4 \pm 0.5(1-10)$ & $147.3 \pm 16.5(33.3-336.0)$ & $61.6 \pm 8.1(9.3-172.4)$ & 30.6 \\
& & Em3 & 11 & $0.7 \pm 0.2(0-3)$ & $62.0 \pm 26.8(8.2-310.7)$ & $99.8 \pm 26.1(8.2-310.7)$ & 12.9 \\
Interruption & $\mathrm{N}$ & Em4 & 8 & $1.4 \pm 0.5(0-8)$ & $0.1 \pm 0.07(0.06-0.6)$ & $0.08 \pm 0.01(0.03-0.13)$ & - \\
& & Em5 & 11 & $43.3 \pm 12.8(5-195)$ & $3.3 \pm 1.8(0.3-21.6)$ & $0.07 \pm 0.01(0.04-0.11)$ & - \\
\hline
\end{tabular}

NPW, no. individuals that produced the specific waveform; NWEI, no. waveform events per insect; WDI, waveform duration per insect ( $\mathrm{min})$; WDEI, waveform duration per event per insect $(\mathrm{min})$; PRT, percentage of recording time.

Em5 was frequently repeated (average of 43 events per insect) during Em3, but was not regularly repetitive (Tables 3 and 4).

\section{Correlations between specific waveforms and stylet tip position in the plant tissue}

Correlation between the behavioural activities and the waveforms recorded during EPG was performed via histological analyses of the plant tissues. During stylet penetration of E. meditabunda towards the ingestion site, a salivary sheath always surrounded the stylets the entire length of the pathway (Figure 7A). For waveform Em1, all tips of stylets severed $(n=3)$ were observed in parenchyma tissue, supporting that Eml represents the stylet pathway through this tissue (Figure 7B). During Em2, all sections $(n=8)$ revealed that both stylet and salivary sheath tips were in xylem cells (Figure 7A and C), and for Em3, all the stylet and salivary sheath tips $(n=6)$ ended in phloem tissue (Figure 7D). In addition, when the stylets of E. meditabunda were severed during Em3, exudation of plant fluid ensued (Figure 8).

\section{Discussion}

Variables affecting wiring success

The removal of cuticular lipids by sanding, in general, greatly improved the retention of the gold wire over time for various species of pentatomids. Sanding of 

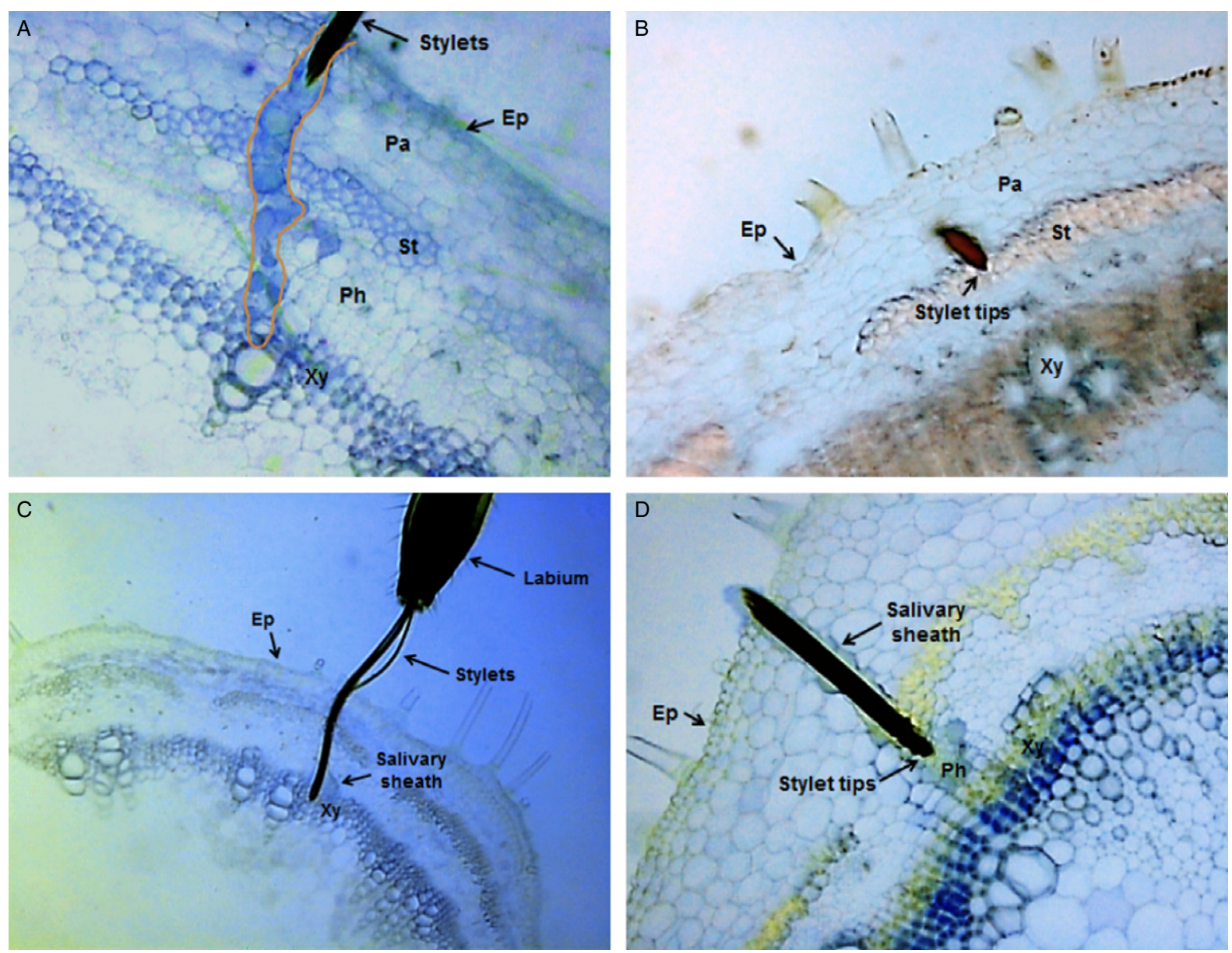

Figure 7 Cross-sections of soybean stem containing stylets and salivary sheaths of Edessa meditabunda on soybean stem. (A) Salivary sheath deeper pathway ending in the ingestion site, xylem $(10 \times)$. (B) Stylet tips ending in parenchyma tissue during waveform Em1 $(10 \times)$. (C) Detail of the stylet tips in the xylem tissue during waveform Em2 (5x). (D) Detail of the stylet tips in phloem tissue (see arrow) during waveform Em3 $(10 \times)$. Ep, stem epidermis; Pa, parenchyma; St, sclerenchyma; Ph, phloem; Xy, xylem. The orange line in A was drawn around the salivary sheath to accentuate the sheath borders.

the pronotum has been successfully done to improve the attachment of harmonic radar tags to the bodies of species of Coleoptera (Boiteau \& Colpitts, 2001; Boiteau et al., 2009) and of the pentatomid Halyomorpha halys (Stål) (Lee et al., 2013) using cyanoacrylate glues. The finding that the size (diameter) of the silver glue drop was greater on sanded than on unsanded bugs may partially explain the better wire attachment.

The generally greater mobility of $P$. guildinii and $N$. viridula explains the lower wire retention for these two species compared to L. deducta. Because P. guildinii turned more frequently than the other two species, it probably caused the wire to break more often; moreover, it is considered a more restless bug than other phytophagous pentatomids (Panizzi \& Smith, 1977). Accordingly, our hypothesis that heavier and bigger bugs would lose the wire attachment more quickly compared with lighter and smaller bugs was not confirmed, regardless of the sanding. Our hypothesis that greater activity and movement on the part of a bug would cause the wire to break more often was supported. Behaviour seems to be an important trait, more relevant for successful wiring than (for instance) body weight.

\section{Characterization of pentatomid waveforms from EPG recordings}

Compared with other piercing-sucking insects, such as aphids, whiteflies, and leafhoppers, little is known about the feeding behaviour of pentatomids using EPG. This is only the sixth published EPG study describing the feeding behaviour of a true bug, and the first to study a pentatomid, in this case E. meditabunda. 


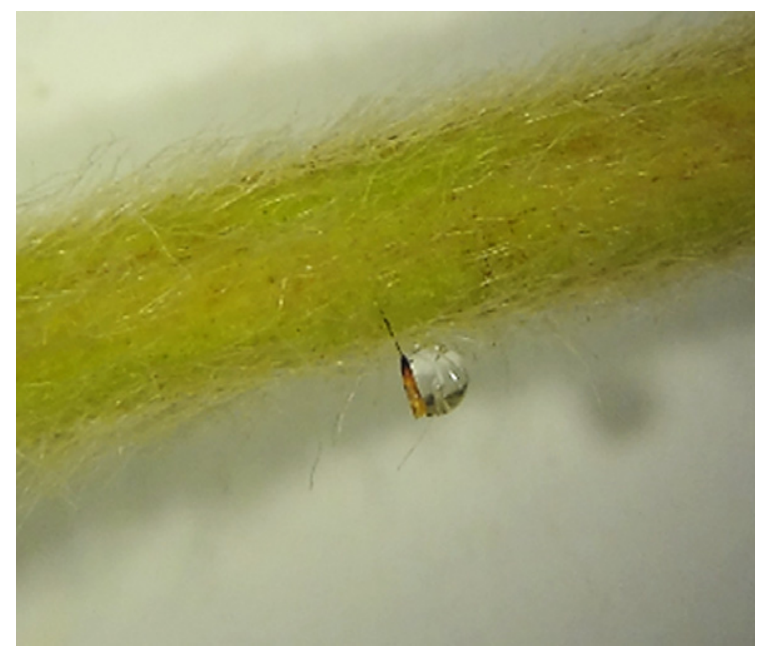

Figure 8 Plant sap exudation out of the severed stylets of Edessa meditabunda after they were cut during ingestion of phloem (waveform Em3).

We found eight EPG waveforms, which were named according to conventions from the literature. Names of waveforms $\mathrm{Np}$ and $\mathrm{Z}$ were based on Youn et al. (2011), the X wave on McLean \& Kinsey (1967), and Backus et al. (2009), and the N and I families on Backus et al. (2005a, 2013) and Miranda et al. (2009). Further waveform types were named based on the initials of the scientific name of the stink bug species studied and then assigned a number, as in Seo et al. (2009).

Our study used the Giga-8 DC EPG monitor, which is pre-set to an input impedance of $10^{9} \Omega$. It is possible that the use of an AC-DC EPG monitor, allowing selectable input impedances from $10^{6}$ to $10^{13} \Omega$, could reveal additional waveforms for pentatomids. Backus et al. (2013) demonstrated that recordings of chinch bugs, Blissus spp., at $10^{9} \Omega$ failed to show the more R-dominant waveforms (those related to resistance) seen at lower input impedance levels.

Pathway phase (Em1). Waveform Em1 always occurred after non-probing (waveforms $\mathrm{Z}$ and $\mathrm{Np}$ ) and was observed for all $E$. meditabunda recorded. This waveform undoubtedly is related to initial stylet penetration into plant tissue. Moreover, Em1 occurred during the secretion of gelling saliva to create the salivary sheath, which was observed in all histological sections correlated with Em1. The waveform Em1 is similar in appearance to waveforms $\mathrm{G}$ and $\mathrm{H}$ observed for the chinch bugs, $B$. insularis and B. occiduus (Backus et al., 2013), waveform S in the sharpshooter Bucephalogonia xanthophis (Berg) (Miranda et al., 2009), as well as $\mathrm{C}$ in aphids (Prado \& Tjallingii,
1994) and the psyllid Diaphorina citri Kuwayama (Bonani et al., 2010; Cen et al., 2012). All these waveforms are reported to represent stylet pathway and salivary sheath secretion. Em1 at the end of the probe probably represented salivary sheath filling (similar to pathway activities), according to Backus et al. (2009) and Miranda et al. (2009).

Ingestion phase: xylem sap ingestion (Em2). The waveform Em2 was strongly correlated with stylet activities in xylem vessels. First, our histological studies with E. meditabunda demonstrated that both stylet tips and salivary sheaths end in xylem cells during Em2. Second, the correlation between Em 2 and xylem activities is strongly supported by electrical evidence, such as positive voltage level (extracellular) and high amplitude of the waveform (Backus et al., 2013). Extracellular voltage is characteristic of xylem ingestion for aphids, leafhoppers, and psyllids (Tjallingii, 1988, 2006; Prado \& Tjallingii, 1994; Miranda et al., 2009; Bonani et al., 2010).

In xylem-ingesting sharpshooter leafhoppers, Dugravot et al. (2008) found that waveform amplitude is proportional to the height of cibarial uplift of the diaphragm, therefore supporting active ingestion of the xylem sap. The high amplitude of Em2 likely is similarly related to the necessity of the stink bug to overcome the high negative pressure of the xylem vessels. Additionally, no change in positive voltage level was observed during Em2, unlike when stylets are puncturing a living cell such as a phloem sieve element. In the latter case, voltage level is usually negative at input impedance of $10^{9} \Omega$.

The appearance of Em2 shows similar characteristics with the waveforms $\mathrm{H}-\mathrm{I} 1$ and $\mathrm{H}-\mathrm{I} 2$ observed for $B$. insularis and B. occiduus (Backus et al., 2013). Likewise, Em2 has similar characteristics to waveform $G$ recorded in aphids (Prado \& Tjallingii, 1994), in the psyllid D. citri (Bonani et al., 2010), in the mealybug Planococcus citri (Risso) (Cid \& Fereres, 2010), and in the leafhopper Circulifer tenellus (Baker) (Stafford \& Walker, 2009). In addition, it resembles the waveform $\mathrm{O} 2$ in the leafhopper Orosius orientalis (Matsumura) (Trębicki et al., 2012), C2 in the sharpshooter Homalodisca vitripennis (Takiya) (Backus et al., 2009), and PG in the psyllid Cacopsylla pyri (L.) (Civolani et al., 2011). All these waveforms have been correlated with active ingestion in xylem [in one case, a similar waveform was also correlated with mesophyll ingestion (Stafford \& Walker, 2009); however, our histological findings did not support ingestion from mesophyll by stink bugs on soybean stems].

No salivation or activities other than ingestion have been correlated with similar-appearing waveforms for any hemipteran species. Thus, we concluded that Em2 
represents active ingestion from 'xylem vessels'. All bugs performed waveform Em2, with on average 3.4 events per individual and of relatively long duration (up to $1 \mathrm{~h}$ ). It is likely that these responses are related to the 18-h starvation period. Similarly, a substantial increase in xylem ingestion for aphids (Spiller et al., 1990; Ramírez \& Niemeyer, 2000; Pompon et al., 2010) and psyllids (Bonani et al., 2010) was observed when they were starved. According to Spiller et al. (1990) and Powell \& Hardie (2002), xylem sap ingestion may be a strategy used for maintaining water balance and avoiding dehydration. In addition, our insects lacked experience feeding on soybean stem prior to recording. Therefore, E. meditabunda may also be using this tactic to recover from the trauma of wiring and inexperience on the host.

Putative phloem contact (the $X$ wave). We observed a short transition waveform, labelled $\mathrm{X}$, which always occurred before E. meditabunda began phloem phase (waveform Em3, see below), and the $\mathrm{X}$ wave was always followed by Em3. In a similar way, Backus et al. (2013), studying the chinch bugs B. insularis and B. occiduus, observed a short phase, labelled J, that always occurred before the bugs began the phloem phase. The chinch bug J wave is thought to be an $\mathrm{X}$ wave, which is analogous to the $\mathrm{X}$ waves recorded for aphids and leafhoppers (Backus et al., 2009). In a similar way, we hypothesized that our transitional waveform was an X wave for E. meditabunda, and named it accordingly.

$\mathrm{X}$ waves are species-specific, stereotypical transition patterns that have been correlated with stylet penetration and subsequent activities inside the preferred ingestion tissue for any vascular piercing-sucking insects using a salivary sheath strategy. These waveforms are a strong indication of penetration and stylet activities in phloem sieve elements by phloem-preferring species (Waydande \& Nault, 1993; Carpane et al., 2011; Backus et al., 2013), or xylem by xylem-preferring species like sharpshooters (Backus et al., 2009). According to these last authors, $X$ waves are thought to represent a combination of salivation, fluid ingestion, and egestion. Consequently, presence of an $\mathrm{X}$ wave supports (along with our histological evidence) that E. meditabunda is a salivary sheath feeder on soybean stem.

Interestingly, our simple $\mathrm{X}$ wave strongly resembled the simple $\mathrm{X}$ wave of the chinch bug when recordings were performed using input impedance of $10^{9} \Omega$ (the same fixed levels as in the Giga8 monitor, which we used). The chinch bug $\mathrm{X}$ wave had more detail and was more complex in appearance when recorded at lower input impedances (Backus et al., 2013). We suspect that a similar change in appearance would occur with $E$. meditabunda X waves, if recorded using an AC-DC monitor at lower input impedances (Backus \& Bennett, 2009).

Ingestion phase: phloem sap ingestion (Em3). Waveform Em3 represents activities in phloem tissue, likely phloem sieve elements. For the chinch bugs B. insularis and B. occiduus, salivation and ingestion in this tissue were named J-I1 and J-I2 (Backus et al., 2013), respectively. The amplitude of these chinch bug waveforms ranged from 5 to $10 \%$, frequency $6.5-9.0 \mathrm{~Hz}$, and intracellular voltage level at input impedance $10^{9} \Omega$. These data are similar to those observed for our waveform Em3 at the same input impedance, in which the amplitude ranged from 5 to $12 \%$, frequency $5.5-8.5 \mathrm{~Hz}$, and intracellular voltage. Moreover, waveform Em3 has similar characteristics to waveforms E1 and E2 of aphids (Prado \& Tjallingii, 1994) and of the psyllids D. citri (Bonani et al., 2010) and Bactericera cockerelli (Sulc) (Pearson et al., 2014), with waves PE1 and PE2 in the psyllid C. pyri (Civolani et al., 2011), D2 and D3 in the leafhopper C. tenellus (Stafford \& Walker, 2009), and E(pd)1 and E (pd) 2 in the whitefly Bemisia tabaci (Gennadius) (Jiang et al., 1999).

The correlation between waveform Em3 and stylets in the phloem is supported by the following: (1) all histological sections showing stylet tips ending in phloem tissue during Em3; (2) negative voltage level (intracellular) inside living phloem sieve elements, as occurs in others insects, such as aphids (Prado \& Tjallingii, 1994), psyllids (Bonani et al., 2010; Cen et al., 2012), and whiteflies (Jiang et al., 1999; Yin et al., 2010); and (3) the low relative amplitude of Em3, suggesting a smaller force to suck the sap of these tissues, that is, a passive ingestion (Backus et al., 2013). Smaller force is necessary because phloem sap is subjected to high internal hydrostatic pressure, which induces the exudation of phloem contents when it is damaged (Taiz \& Zeiger, 2004). Indeed, when certain stink bug probes were artificially terminated during waveform Em 3 then the stylets were cut, exudation of fluid occurred, demonstrating the positive pressure. Similar exudation has also been observed by Seo et al. (2009) for the planthopper Nilaparvata lugens (Stål), when its stylets were cut off during the waveform N4-b (phloem sap ingestion). All of the above evidence supports that Em3 represents (at least) phloem sap ingestion.

Phloem phase in many piercing-sucking insects often is composed of two distinct waveforms correlated with salivation and sap ingestion in sieve elements. For example, in aphids, the salivation and sap ingestion are named waveforms E1 and E2, respectively. In contrast, two separate waveform types could not be clearly distinguished in the stink bug E. meditabunda. Either salivation (1) does not 
occur sequentially preceding ingestion in stink bugs, (2) occurs simultaneously and is combined in the same waveform (Em3), or (3) is restricted to interruptions only (see below) so that only ingestion occurs during Em3. Present results cannot distinguish among these three possibilities. More studies are needed to better elucidate this uncertainty. Despite aphid E2 being called 'phloem ingestion', it is thought to occur simultaneously with salivation (Tjallingii, 2006). Therefore, we will tentatively designate Em3 as phloem sap ingestion.

Finally, the sinuous pattern of Em3 might be similar to the sinuous changes in voltage levels of the aphid E2 waveform, recently found to be caused by depolarization of the sieve element cell membrane for plant signal transduction conveying information about plant damage (SalvadorRecatalà et al., 2014). In other words, the insect's stylets may be acting as an electrophysiological electrode to pick up plant-derived signals that are superimposed on the insect-derived ingestion signals.

Interruption phase: injections of saliva into xylem and phloem (Em4 and Em5). We observed the occurrence of brief interruptions during both xylem- and phloemassociated waveforms. In xylem vessel ingestion (Em2), $32 \%$ of the recorded insects showed these interruptions, which were named waveform Em4, and 100\% of insects in phloem sap ingestion (Em3), named waveform Em5. Em4 is similar to the other interruption waveforms discussed in the literature (named waveform $\mathrm{N}$ ), for example, described in xylem ingestion of the sharpshooters Homalodisca coagulata (Say) (Backus et al., 2005a) and B. xanthophis (Miranda et al., 2009) and the chinch bugs B. insularis and B. occiduus (Backus et al., 2013). According to Backus et al. (2005a, 2013), the interruptions may represent watery salivation and putative tasting/testing of xylem cells. These responses were observed via histological correlations of the interruptions for the sharpshooter $H$. vitripennis (the renamed H. coagulata) (Backus et al., 2012).

We propose that xylem ingestion interruptions (Em4) performed by $E$. meditabunda also may be related to salivary secretion and testing of xylem cells, because this waveform, when recorded, occurred mainly in the early stages of xylem ingestion. Furthermore, interruptions have not been recorded previously during phloem sap ingestion, where, according to Backus et al. (2013), for chinch bugs, absence of waveform $\mathrm{N}$ in this tissue may indicate that the sole salivation waveform in sieve tubes is waveform J-I1. For stink bugs, it is possible that Em5 represents the sole salivation behaviour in phloem, interspersed among ingestion (Em3) events, rather than at the start of phloem phase, as in aphids.

\section{Conclusions}

Our results demonstrate that sanding the pronotum of stink bugs greatly improved wire attachment and that bug movement is the most important trait affecting the quality of wire fixation. EPG recordings of E. meditabunda on soybean stems generated eight types of waveforms, which were electrically characterized and correlated via histology and sap exudation. Edessa meditabunda, unlike other pentatomid pests of soybean, prefers to feed on stems rather than on pods (Silva et al., 2012). Based on electrical characteristics and histological analyses, we found evidence that, at least on soybean stem, E. meditabunda is a salivary sheath feeder and that ingestion occurs in both xylem vessels and phloem sieve elements. Our findings show that the Em2 waveform, representing xylem ingestion, was the most dominant one during recording. However, it is presently unknown whether this represents ingestion preference for xylem over phloem, or is the result of stress from long starvation, wiring, and inexperience feeding on soybean stems. In any case, characterization of our eight DC EPG waveforms of $E$. meditabunda will now make possible many future studies of the feeding of this important soybean pest insect.

\section{Acknowledgements}

We thank Elaine Backus and Paula Levin Mitchell for critically reading an early version of the manuscript. We also thank PL Mitchell for helping us to set up and learn how to use the Giga-8 DC EPG, and Julio Cesar Ventura for providing us the dental sandpaper. Valdirene Volpato helped us to take the microscope photographs. Paulo R.V.S. Pereira helped to edit the figures. This paper is part of the doctoral research work of TL, in order to obtain the Doctor of Science (Entomology) degree at the Federal University of Paraná at Curitiba, Brazil. He was supported by a scholarship from CAPES (Ministry of Education) of Brazil.

\section{References}

Almeida R \& Backus EA (2004) Stylet penetration behaviours of Graphocephala atropunctata (Say): EPG waveforms characterization and quantification. Annals of the Entomological Society of America 97: 838-851.

Backus EA \& Bennett WH (2009) The AC-DC Correlation Monitor: new EPG design with flexible input resistors to detect both $\mathrm{R}$ and emf components for any piercing-sucking hemipteran. Journal of Insect Physiology 55: 869-884.

Backus EA, Habibi J, Yan F \& Ellersieck M (2005a) Stylet penetration by adult Homalodisca coagulata on grape: electrical 
penetration graph waveform characterization, tissue correlation, and possible implications for transmission of Xylella fastidiosa. Annals of the Entomological Society of America 98: 787-813.

Backus EA, Serrano MS \& Ranger CM (2005b) Mechanisms of hopperburn: an overview of insect taxonomy, behavior, and physiology. Annual Review of Entomology 50: 125-151.

Backus EA, Cline AR, Ellerseick MR \& Serrano MS (2007) Lygus hesperus (Hemiptera: Miridae) feeding on cotton: new methods and parameters for analysis of nonsequential electrical penetration graph data. Annals of the Entomological Society of America 100: 296-310.

Backus EA, Holmes WJ, Schreiber F, Reardon BJ \& Walker GP (2009) Sharpshooter X wave: correlation of an electrical penetration graph waveform with xylem penetration supports a hypothesized mechanism for Xylella fastidiosa inoculation. Annals of the Entomological Society of America 102: 847-867.

Backus EA, Andrews KB, Shugart HJ, Greve LC, Labavitch JM \& Alhaddad H (2012) Salivary enzymes are injected into xylem by the glassy-winged sharpshooter, a vector of Xylella fastidiosa. Journal of Insect Physiology 58: 949-959.

Backus EA, Rangasamy M, Stamm M, Mcauslane HJ \& Cherry R (2013) Waveform library for chinch bugs (Hemiptera: Heteroptera: Blissidae): characterization of electrical penetration graph waveforms at multiple input impedances. Annals of the Entomological Society of America 106: 524-539.

Boiteau G \& Colpitts B (2001) Electronic tags for the tracking of insects in flight: effect of weight on flight performance of adult Colorado potato beetles. Entomologia Experimentalis et Applicata 100: 187-193.

Boiteau G, Meloche F, Vincent C \& Leskey TC (2009) Effectiveness of glues used for harmonic radar tag attachment and impact on survival and behavior of three insect pests. Environmental Entomology 38: 168-175.

Bonani JP, Fereres A, Garzo E, Miranda MP, Appezzato-daGloria B \& Lopes JRS (2010) Characterization of electrical penetration graphs of the Asian citrus psyllid, Diaphorina citri, in sweet orange seedlings. Entomologia Experimentalis et Applicata 134: 35-49.

Bonjour EL, Fargo WS, Webster JA, Richardson PE \& Brusewitz GH (1991) Probing behavior comparisons of squash bugs (Heteroptera: Coreidae) on cucurbit hosts. Environmental Entomology 20: 143-149.

Calatayud PA, Rahbé Y, Tjallingii WF, Tertuliano M \& Le Rü B (1994) Electrical recording feeding behavior of cassava mealybug on host and non-host plants. Entomologia Experimentalis et Applicata 72: 219-232.

Calatayud PA, Seligmann CD, Polania MA \& Bellotti AC (2001) Influence of parasitism by encyrtid parasitoids on the feeding behaviour of the cassava mealybug Phenacoccus herreni. Entomologia Experimentalis et Applicata 98: 271-278.

Carpane P, Wayadande A, Backus E, Dolezal W \& Fletcher J (2011) Characterization and correlation of new electrical penetration graph waveforms for the corn leafhopper (Hemiptera: Cicadellidae). Annals of the Entomological Society of America 104: 515-525.
Cen Y, Yang C, Holford P, Beattie GAC, Spooner-Hart RN et al. (2012) Feeding behaviour of the Asiatic citrus psyllid, Diaphorina citri, on healthy and huanglongbing-infected citrus. Entomologia Experimentalis et Applicata 143: 13-22.

Cid M \& Fereres A (2010) Characterization of the probing and feeding behavior of Planococcus citri (Hemiptera: Pseudococcidae) on grapevine. Annals of the Entomological Society of America 103: 404-417.

Civolani S, Leis M, Grandi G, Garzo E, Pasqualini E et al. (2011) Stylet penetration of Cacopsylla pyri; an electrical penetration graph (EPG) study. Journal of Insect Physiology 57: 14071419.

Cline AR \& Backus EA (2002) Correlations among AC electronic monitoring waveforms, body postures, and stylet penetration behaviors of Lygus hesperus (Hemiptera: Miridae). Environmental Entomology 31: 538-549.

Cook CA \& Neal JJ (1999) Feeding behavior of larvae of Anasa tristis (Heteroptera: Coreidae) on pumpkin and cucumber. Environmental Entomology 28: 173-177.

Dugravot S, Backus EA, Reardon BJ \& Miller TA (2008) Correlations of cibarial muscle activities of Homalodisca spp. sharpshooters (Hemiptera: Cicadellidae) with EPG ingestion waveform and excretion. Journal of Insect Physiology 54: $1467-1478$.

Hori K (2000) Possible causes of disease symptoms resulting from the feeding of phytophagous Heteroptera. Heteroptera of Economic Importance (ed. by CW Schaefer \& AR Panizzi), pp. 11-35. CRC Press, Boca Raton, FL, USA.

Hori K, Kondo Y \& Kuramochi K (1984) Feeding site of Palomena angulosa Motschulsky (Hemiptera: Pentatomidae) on potato plants and injury caused by the feeding. Applied Entomology and Zoology 19: 476-482.

Janssen JAM, Tjallingii WF \& van Lenteren JC (1989) Electrical recording and ultrastructure of stylet penetration by the greenhouse whitefly. Entomologia Experimentalis et Applicata 52: 69-81.

Jiang YX, Lei H, Collar JL, Martin B, Muñiz M \& Fereres A (1999) Probing and feeding behavior of two distinct biotypes of Bemisia tabaci (Homoptera: Aleyrodidae) on tomato plants. Journal of Economic Entomology 92: 357-366.

Jiang YX, Nombela G \& Muñiz M (2001) Analysis by DC-EPG of the resistance to Bemisia tabaci on Mi-tomato line. Entomologia Experimentalis et Applicata 99: 295-302.

Jin S, Chen ZM, Backus EA, Sun XL \& Xiao B (2012) Characterization of EPG waveforms for the tea green leafhopper, Empoasca vitis Göthe (Hemiptera: Cicadellidae), on tea plants and their correlation with stylet activities. Journal of Insect Physiology 58: 1235-1244.

Lee DH, Wright SE, Boiteau G, Vincent C \& Leskey TC (2013) Effectiveness of glues for harmonic radar tag attachment on Halyomorpha halys (Hemiptera: Pentatomidae) and their impact on adult survivorship and mobility. Environmental Entomology 42: 515-523.

McLean DL \& Kinsey MG (1964) A technique for electronically recording aphid feeding and salivation. Nature 202: 13581359. 
McLean DL \& Kinsey MG (1965) Identification of electrically recorded curve patterns associated with aphid salivation and ingestion. Nature 205: 1130-1131.

McLean DL \& Kinsey MG (1967) Probing behavior of the pea aphid, Acyrthosiphon pisum. I. Definitive correlation of electronically recorded waveforms with aphid probing activities. Annals of the Entomological Society of America 60: 400-405.

Miranda MP, Fereres A, Appezzato-da-Gloria B \& Lopes JRS (2009) Characterization of electrical penetration graphs of Bucephalogonia xanthophis, a vector of Xylella fastidiosa in citrus. Entomologia Experimentalis et Applicata 130: 35-46.

Panizzi AR \& Smith JG (1977) Biology of Piezodorus guildinii: oviposition, development time, adult sex ratio and longevity. Annals of the Entomological Society of America 70: 35-39.

Pearson CC, Backus EA, Shugart HJ \& Munyaneza JE (2014) Characterization and correlation of EPG waveforms of Bactericera cockerelli (Hemiptera: Triozidae): variability in waveform appearance in relation to applied signal. Annals of the Entomological Society of America 107: 650-666.

Pompon J, Quiring D, Giordanengo P \& Pelletier Y (2010) Role of xylem consumption on osmoregulation in Macrosiphum euphorbiae (Thomas). Journal of Insect Physiology 56: 610615.

Powell G \& Hardie J (2002) Xylem ingestion by winged aphids. Entomologia Experimentalis et Applicata 104: 103-108.

Prado E \& Tjallingii WF (1994) Aphid activities during sieve element punctures. Entomologia Experimentalis et Applicata 72: 157-165.

R Development Core Team (2014) R: A Language and Environment for Statistical Computing. R Foundation for Statistical Computing, Vienna, Austria.

Ramírez CC \& Niemeyer HM (2000) The influence of previous experience and starvation on aphid feeding behavior. Journal of Insect Behavior 13: 699-709.

Salvador-Recatalà V, Tjallingii WF \& Farmer EE (2014) Real time, in vivo intracellular recordings of caterpillar-induced depolarization waves in sieve elements using aphid electrodes. New Phytologist 203: 674-684.

Seo BY, Kwon YH, Jung JK \& Kim GH (2009) Electrical penetration graphic waveforms in relation to the actual positions of the stylet tips of Nilaparvata lugens in rice tissue. Journal of Asia-Pacific Entomology 12: 89-95.

Silva FAC, Silva JJ, Depieri RA \& Panizzi AR (2012) Feeding activity, salivary amylase activity, and superficial damage to soybean seed by adult Edessa meditabunda (F.) and Euschistus heros (F.) (Hemiptera: Pentatomidae). Neotropical Entomo$\operatorname{logy} 41: 386-390$.

Sosa-Gomez DR, Boucias DG \& Nation JL (1997) Attachment of Metarhizium anisopliae to the southern green stink bug Nezara viridula cuticle and fungistatic effect of cuticular lipids and aldehydes. Journal of Invertebrate Pathology 69: 31-39.

Spiller NJ, Koenders L \& Tjallingii WF (1990) Xylem ingestion by aphids - a strategy for maintaining water balance. Entomologia Experimentalis et Applicata 55: 101-104.

Stafford CA \& Walker GP (2009) Characterization and correlation of DC electrical penetration graph waveforms with feeding behavior of beet leafhopper, Circulifer tenellus. Entomologia Experimentalis et Applicata 130: 113-129.

Stafford CA, Walker GP \& Creamer R (2009) Stylet penetration behavior resulting in inoculation of beet severe curly top virus by beet leafhopper, Circulifer tenellus. Entomologia Experimentalis et Applicata 130: 130-137.

Suzuki Y \& Hori M (2014) Diurnal locomotion and feeding activities of two rice-ear bugs, Trigonotylus caelestialium and Stenotus rubrovittatus (Hemiptera: Heteroptera: Miridae). Applied Entomology and Zoology 49: 149-157.

Taiz L \& Zeiger E (2004) Plant Physiology, 3rd edn. Sinauer Associates, Sunderland, MA, USA.

Tjallingii WF (1978) Electronic recording of penetration behaviour by aphids. Entomologia Experimentalis et Applicata 24: 721-730.

Tjallingii WF (1985) Electrical nature of recorded signals during stylet penetration by aphids. Entomologia Experimentalis et Applicata 38: 177-186.

Tjallingii WF (1988) Electrical recording of stylet penetration activities. Aphids: Their Biology, Natural Enemies and Control, Vol. 2B (eds. by AK Minks \& P Harrewjin), pp. 95-108. Elsevier, Amsterdam, The Netherlands.

Tjallingii WF (2006) Salivary secretions by aphids interacting with proteins of phloem wound responses. Journal of Experimental Botany 57: 739-745.

Trębicki P, Tjallingii WF, Harding RM, Rodoni BC \& Powell KS (2012) EPG monitoring of the probing behaviour of the common brown leafhopper Orosius orientalis on artificial diet and selected host plants. Arthropod-Plant Interactions 6: 405-415.

Waydande AC \& Nault LR (1993) Leafhopper probing behaviour associated with maize chlorotic dwarf virus transmission to maize. Phytopathology 83: 522-526.

Yin HD, Wang XY, Xuel K, Huang CH, Wang RJ et al. (2010) Impacts of transgenic Bt cotton on the stylet penetration behaviors of Bemisia tabaci biotype B: evidence from laboratory experiments. Insect Science 17: 344-352.

Youn Y, Backus EA, Serikawa RH \& Stelinski LL (2011) Correlation of an electrical penetration graph waveform with walking by Asian citrus psyllid, Diaphorina citri (Hemiptera: Psyllidae). Florida Entomologist 94: 1084-1087. 